\title{
Culture, innovation, and economic development
}

\author{
Pantelis C. Kostis ${ }^{1,2}$
}

\author{
Correspondence: pkostis@econ.uoa. \\ gr \\ 'Department of Economics, \\ National and Kapodistrian University \\ of Athens, Athens, Greece \\ 2Department of Business \\ Administration, Hellenic Open \\ University, Patras, Greece
}

\begin{abstract}
During recent decades, culture is gaining more and more attention as a factor that determines economic outcomes. Trying to investigate its role on innovation and economic development, this paper uses a dataset that offers the potential for a cross-sectional and time series analysis. Thus, in this paper, the effects of culture on innovation (as measured by patent applications, spending on R\&D, number or researchers per 1000 individuals and number of government researchers) and economic development are investigated. Cultural background is captured through the Schwartz's cultural values, as reported through the European Social Survey (ESS) waves during the period 2002-2018. The dataset is comprised by 18 Eurozone countries. Using principal component analyses to capture the Schwartz's cultural values, as well as two ways fixed-effects analysis (FE), time dummies for each ESS wave included in the analysis and cluster-robust estimates of the standard errors, in order to examine the above relationships, the main conclusions derived from the analysis are that (a) there is significant effect of culture on innovation and economic development, and (b) the main cultural dimensions that hinder innovation and economic development are the prevalence of hierarchy, affective autonomy, and mastery. These results hold for all different dependent variables used in the analysis. Thus, when hierarchy, affective autonomy, and mastery are present innovation and economic development are hindered, leading to obstacles regarding the sustainability of economic outcomes. The opposite holds in societies where embeddedness, egalitarianism, and harmony prevail.
\end{abstract}

Keywords: Culture, Economic Development, Innovation, Schwartz

\section{Introduction}

The cultural background and the values of which it is composed interact in a complex way with the economic system. The economic system is defined as the grid of human institutions (North, 1990) and motivations that shape the two main variables: the growth rate of the economies and the way the income and wealth are distributed, which in turn leads to the economic outcomes (Petrakis, 2014; Petrakis \& Kostis, 2013). Thus, culture can be considered a strategic instrument (Petrakis et al., 2015) that affects economic outcomes whether directly or indirectly. Moreover, the cultural background of the societies affects the effectiveness of economic policy, since a society has to approve firstly an economic policy in order to make it more

(c) The Author(s). 2021 Open Access This article is licensed under a Creative Commons Attribution 4.0 International License, which permits use, sharing, adaptation, distribution and reproduction in any medium or format, as long as you give appropriate credit to the original author(s) and the source, provide a link to the Creative Commons licence, and indicate if changes were made. The images or other third party material in this article are included in the article's Creative Commons licence, unless indicated otherwise in a credit line to the material. If material is not included in the article's Creative Commons licence and your intended use is not permitted by statutory regulation or exceeds the permitted use, you will need to obtain permission directly from the copyright holder. To view a copy of this licence, visit http://creativecommons.org/licenses/by/4.0/. 
effective (Kafka, 2020; Kafka et al., 2020). In addition, culture is reported as a way to increase entrepreneurial value (Fernandez-Jardon et al., 2020; Michna \& Kmieciak, 2020; Molina-Ramirez \& Barba-Sanchez, 2021; Park et al., 2021), innovation (Mohamad et al., 2020; Ober, 2020; Zhen et al., 2021), and sustainable development and performance (Adebayo et al., 2020; Carta et al., 2020).

It is worth investigating not only the way the cultural background is interconnected with economic development (Harrison \& Huntington, 2000), but also how this interconnection takes place (Triandis, 2009). In other words, it matters whether culture is linked to economic development, but even more important is whether culture is changed, in what way and to what extent. Only then can we will be ready to understand whether cultural background can influence (and how much) economic development.

The present paper, aims to present the role of culture on innovation and economic development, using a dataset comprised from data concerning the last two decades for the Eurozone countries. In doing so, the analysis considers culture as a moving structure and not as stable as most studies in the relevant literature do.

The structure of the paper is as follows: in the "Literature review" section, a literature review is presented regarding how culture affects innovation and economic development. "Data and methodology" section presents the data used in the empirical analysis, as well as the methodology employed. Then comes ("Results and discussion" section) the presentation of the empirical results. Finally, in the "Conclusions" section, there are presented the basic conclusions of the overall analysis.

\section{Literature review}

The effects of culture on innovation performance is not a new one in the relevant literature (Leal-Rodriguez et al., 2014; Petrakis, 2014; Yun et al., 2020), since culture seems to be a critical element for the process of technological development and explains the technological differences between countries. The grid of values that characterize a society may act as an enhancer or as a brake to realize innovations (LealRodriguez et al., 2014; Petrakis, 2014; Petrakis et al., 2015; Petrakis et al., 2016; Ulijn \& Weggeman, 2001; Westwood \& Low, 2003). This grid mainly concerns the levels of individuality/collectivity of the society, the degree of aversion to risk, the orientation and planning for the future, and the acceptance of inequalities (power distance) (Petrakis, 2014).

The basic way through which culture leads towards innovation outcomes is the fact that culture is responsible for creating an environment that may hinder or promote innovation through the effects it has on the existence of free exchange of ideas between individuals in a society. According to Jaskyte and Dressler (2004), culture should be considered as integral to the innovation outcomes since the innovation procedures involve learning and developing new ideas.

Innovation is boosted in cultures that motivate social progress and reward productivity, is long-term oriented, and accept changes (Rothwell \& Wissema, 1986) while it is hindered in risk averse cultures that which are not willing to invest in new technologies and thus innovate less (Hofstede, 1980; Shane, 1993; Shane, 1995).

Moreover, different attitudes towards business formation have been observed depending on culture (Shapero \& Sokol, 1982). Privacy is positively correlated to innovation 
outcomes due to the fact that when individuals feel free and willing to express their ideas, they innovate more (Barnett, 1953).

In addition, according to Hofstede (1984) individualistic societies and those that do not accept inequalities in the way power is distributed (low power distance) appear to have a stronger tendency for innovation (Hofstede, 1984). The diversity of cultural characteristics can be a factor that stimulates innovation (Majidi, 2010).

Moreover, Schwartz (1992; 2004; 2006) points out that the cultural values of hierarchy and integration into groups stifle the motivation and creativity of individuals, while equalitarianism-supported by small families-leads to individuals that develop their own abilities and interests. He also points out that investments are higher for societies with low scores on group integration and equity but also that harmony encourages international investment.

Moreover, Petrakis et al. (2015) point out that culture should be seen as a strategic instrument which can be used in order to determine innovation and competitiveness of the economies, since it can significantly affect economic development and growth. Thus, although there may exist macroeconomic conditions that hinder growth, cultures that promote innovation could perform much better in the future.

Kafka et al. (2020) argue that another critical element regarding the future economic outcomes is the coevolution process between institutions and culture. They point out that economic development and growth is facilitated only when this coevolution is on an optimal pattern.

\section{Data and methodology}

To investigate the relationship between innovation, economic development, and culture, an unbalanced panel dataset is used for the period from 2002 up to 2018, for the Eurozone countries ${ }^{1}$. The choice of the time period under consideration is determined by the availability of data regarding culture, based on the European Social Survey (ESS) waves that have been released during that period. ESS waves are offered for a panel data analysis since the waves are released every 2 years, while other similar studies such as the World Values Survey and the European Values Study release their waves more slowly (every $3-5$ years). Moreover, this is the first time, cultural background is used to determine innovation output and economic development using such time-densely data, since most studies use culture as a constant structure.

Based on previous works that try to examine the effects of culture on economic outcomes (Bakas et al., 2020; Kostis et al., 2018), the following two equations are estimated in order to examine the effects of culture on innovation and economic development:

$$
\begin{aligned}
& \text { Innovation }_{i t}=a_{i}+\beta \text { Culture }_{i t}+\lambda_{t}+u_{i t}, \\
& \text { Economic Development } \\
& \text { E }_{t}=\gamma_{i}+\delta \text { Culture }_{i t}+\lambda_{t}+w_{i t},
\end{aligned}
$$

where $i$ denotes the economies of the Eurozone $\left(N_{\max }=18\right)$ and $t$ is the ESS wave under analysis $\left(T_{\max }=9\right)$. The dependent variable in the first equation Innovation is a vector of variables that represent the innovation output, the dependent variable in the second equation Economic Development is measured by the GDP per capita (in US

${ }^{1}$ Malta in not included in the analysis, due to unavailable data regarding the cultural background. 
dollars) as reported by the Organization for Economic Co-operation and Development (OECD) (2021), the independent variable Culture is a vector of variables that represent the cultural background dimensions as described by Schwartz (1992; 2006), $a_{i}$ is a constant term that captures the country-specific fixed effects and which records the country-specific time-invariant heterogeneity, and $\lambda_{t}$ is a set of dummies that control for specific effects per wave that are common to all economies under analysis.

As in Kostis et al. (2018) and Bakas et al. (2020), the estimation of Eqs. (1) and (2) is done through the two ways fixed-effects analysis (FE), which allows the economyspecific heterogeneity using a different constant term per economy. Both estimations use the standard ordinary least squares method (OLS). In addition, time dummies for each wave are included in order to incorporate in the analysis time effects that are common to all countries in the sample. In addition, cluster-robust estimates of the standard errors were taken into account in order to control for the autocorrelation and heteroskedasticity for each economy. All estimation were realized using the Stata/MP 13.0 version.

Regarding Innovation four different measures are used in order to lead to more robust results. There are (a) the number of Patent Applications realized by residents as reported by the World Bank. (b) The Gross domestic spending on Research and Development (RED) as a GDP percentage as reported by OECD (2021). (c) The number of Researchers per 1000 people employed as reported by OECD (2021). (d) The number of Government Researchers as reported by OECD (2021).

Regarding the cultural background the cultural values reported by Schwartz (1992) are used. Schwartz (1992; 2004; 2006), with his theory of cultural values, seeks to define a relationship between culture and important social circumstances. These are seven cultural values in total that form three bipolar dimensions based on the responses of individuals to basic problems that refer to the way each individual is connected to a group, whether individuals behave in a socially responsible manner and which is the way individuals are linked to their environment and nature. The three bipolars are (Schwartz, 1992): "conservatism/embeddedness vs autonomy," "hierarchy vs egalitarianism," and "mastery vs harmony."

In addition to Schwartz's analysis about prevailing cultural values, Smith and Schwartz (1997) present a theory of human values and how these values relate to cultural values. According to them human values are a critical element in order to explain different behaviors among individuals and societies and may be considered as the beliefs of the society and what motivates human action. In their analysis, they end up in 10 broad values which concern the whole world since these are based in specific requirements of social existence. The 10 values are self-direction, stimulation, hedonism, achievement, power, security, conformity, tradition, benevolence, and universalism.

The ESS questionnaire in all nine waves released up to now-from 2002 up to 2018 - presents a measure of the 10 human values as developed by Smith and Schwartz (1997), through specific questions as those presented in the second column of Table 1. Based on Smith and Schwartz (1997), and Schwartz (2012), those human values are linked to the specific bipolars of cultural values. Table 1 relates human values to cultural values, based on the specific questions that appear in the waves of the ESS. The 
Table 1 Linking Schwartz's values to relevant ESS questions

\begin{tabular}{|c|c|c|}
\hline Human values & ESS questions & Cultural values \\
\hline Self-direction & Important to think new ideas and being creative & $\begin{array}{l}\text { Conservatism/embeddedness } \\
\text { vs autonomy }\end{array}$ \\
\hline \multirow[t]{4}{*}{ Stimulation } & Important to try new and different things in life & Embeddedness \\
\hline & Important to have a good time & \\
\hline & Important to seek adventures and have an exciting life & \\
\hline & Important to seek fun and things that give pleasure & \\
\hline Hedonism & Important to understand different people & Intellectual autonomy \\
\hline \multirow[t]{2}{*}{ Achievement } & Important to show abilities and be admired & Affective autonomy \\
\hline & $\begin{array}{l}\text { Important to be successful and that people recognize } \\
\text { achievements }\end{array}$ & \\
\hline \multirow[t]{2}{*}{ Power } & Important to be rich, have money, and expensive things & Hierarchy vs egalitarianism \\
\hline & Important to do what is told and follow rules & \\
\hline \multirow[t]{2}{*}{ Security } & Important to live in secure and safe surroundings & Hierarchy \\
\hline & Important that government is strong and ensures safety & \\
\hline Conformity & Important to behave properly & Egalitarianism \\
\hline \multirow[t]{2}{*}{ Tradition } & Important to get respect from others & Mastery vs harmony \\
\hline & Important to follow traditions and customs & \\
\hline \multirow[t]{3}{*}{ Benevolence } & $\begin{array}{l}\text { Important that people are treated equally and have equal } \\
\text { opportunities }\end{array}$ & Mastery \\
\hline & Important to help people and care for others well-being & \\
\hline & Important to be loyal to friends and devote to people close & \\
\hline Universalism & Important to care for nature and environment & Harmony \\
\hline
\end{tabular}

percentage of those who answered "Very Much Like Me" in those questions is used in order to have the percentage of people that is highly expressed by those values.

In Table 2, the descriptive statistics for the dependent variables are presented as well as the ESS questions through which the Schwartz's cultural values are captured.

Then, based on previous works (Bakas et al., 2020; Kostis et al., 2018; Petrakis \& Kostis, 2013) using cultural data, principal component analyses (PCA) are realized in order to capture the cultural values dipoles "conservatism/embeddedness vs autonomy," "hierarchy vs egalitarianism," and "mastery vs harmony" based on the ESS questions that are related with each human value which corresponds to specific cultural values. PCA offers the opportunity to reduce the number of the variables, creating principal components that are characterized based on the specific values that configure them out.

\section{Results and discussion}

Table 3 presents a correlation matrix between the ESS questions. The questions used in the analysis present high correlation between each other, something that allows for using PCA in order to capture the overall culture measure and the Schwartz's cultural values.

Moreover, Table 4 presents the PCA for the "conservatism/embeddedness vs autonomy" cultural value.

\footnotetext{
${ }^{2}$ In these questions, the respondents have to choose between the following choices: "Very much like me," "Like me," "Somewhat like me," "A little like me," "Not like me," "Not like me at all."
} 
Table 2 Descriptive statistics of the variables used in the analysis

\begin{tabular}{|c|c|c|c|c|c|c|}
\hline & & $\mathbf{N}$ & Med. & Stdev & Min & Max \\
\hline \multicolumn{2}{|l|}{ Patent applications } & 147 & 4871.5 & 11587.7 & 3 & 49240 \\
\hline \multicolumn{2}{|c|}{ Gross domestic spending on R\&D } & 153 & 1.6 & 0.8 & 0 & 4 \\
\hline \multicolumn{2}{|c|}{ Researchers per 1000 people employed } & 152 & 7.4 & 2.9 & 3 & 17 \\
\hline \multicolumn{2}{|c|}{ Government researchers } & 147 & 10702.7 & 15229.9 & 331 & 66978 \\
\hline \multicolumn{2}{|c|}{ Economic development } & 153 & 36.9 & 17.9 & 10.1 & 120.1 \\
\hline \multirow{8}{*}{$\begin{array}{l}\text { Conservatism/ } \\
\text { embeddedness vs } \\
\text { autonomy }\end{array}$} & $\begin{array}{l}\text { Important to think new ideas and being } \\
\text { creative }\end{array}$ & 118 & 19.5 & 5.7 & 7.7 & 35.8 \\
\hline & $\begin{array}{l}\text { Important to try new and different things } \\
\text { in life }\end{array}$ & 116 & 13.7 & 4.2 & 5.8 & 29.4 \\
\hline & Important to have a good time & 118 & 12.5 & 6.5 & 3.3 & 31.5 \\
\hline & $\begin{array}{l}\text { Important to seek adventures and have an } \\
\text { exciting life }\end{array}$ & 118 & 5.5 & 2.2 & 1.5 & 14.3 \\
\hline & $\begin{array}{l}\text { Important seek fun and things that give } \\
\text { pleasure }\end{array}$ & 114 & 13.2 & 5.4 & 1.5 & 27.0 \\
\hline & Important to understand different people & 117 & 19.6 & 6.5 & 4.8 & 32.7 \\
\hline & Important to show abilities and be admired & 116 & 9.8 & 5.5 & 3.0 & 28.8 \\
\hline & $\begin{array}{l}\text { Important to be successful and that people } \\
\text { recognize achievements }\end{array}$ & 114 & 8.7 & 4.8 & 3.8 & 29.4 \\
\hline \multirow[t]{5}{*}{$\begin{array}{l}\text { Hierarchy vs } \\
\text { egalitarianism }\end{array}$} & $\begin{array}{l}\text { Important to be rich, have money and } \\
\text { expensive things }\end{array}$ & 116 & 2.2 & 2.3 & 0.4 & 12.2 \\
\hline & Important to do what is told and follow rules & 116 & 9.2 & 3.5 & 3.6 & 21.3 \\
\hline & $\begin{array}{l}\text { Important to live in secure and safe } \\
\text { surroundings }\end{array}$ & 116 & 24.0 & 11.5 & 3.6 & 63.7 \\
\hline & $\begin{array}{l}\text { Important that government is strong and } \\
\text { ensures safety }\end{array}$ & 116 & 25.7 & 11.5 & 9.1 & 67.6 \\
\hline & Important to behave properly & 116 & 15.2 & 6.7 & 6.7 & 33.4 \\
\hline \multirow[t]{6}{*}{ Mastery vs harmony } & Important to get respect from others & 118 & 10.0 & 6.4 & 2.1 & 35.1 \\
\hline & Important follow traditions and customs & 118 & 16.2 & 9.8 & 2.1 & 48.4 \\
\hline & $\begin{array}{l}\text { Important that people are treated equally } \\
\text { and have equal opportunities }\end{array}$ & 113 & 32.3 & 9.8 & 14.9 & 57.6 \\
\hline & $\begin{array}{l}\text { Important to help people and care for others } \\
\text { well-being }\end{array}$ & 116 & 25.1 & 8.7 & 8.7 & 48.8 \\
\hline & $\begin{array}{l}\text { Important to be loyal to friends and devote } \\
\text { to people close }\end{array}$ & 120 & 35.5 & 10.0 & 10.5 & 52.4 \\
\hline & Important to care for nature and environment & 116 & 31.4 & 8.0 & 13.2 & 54.6 \\
\hline
\end{tabular}

$N$ denotes the number of observations, Med. the median, Stdev the standard deviation, Min the minimum value, and Max the maximum value

The first two principal components (PC) are used. The first one has an eigenvalue of 4.42 and is related to $55.28 \%$ of total variance. It is positively configured by the following questions: "Important to think new ideas and being creative" and "Important to try new and different things in life." In that way, it is a component that is characterized by self-direction and stimulation.

The second one has an eigenvalue of 1.43 and is related to $17.89 \%$ of total variance. It is positively configured by the following questions: "Important to show abilities and be admired" and "Important to be successful and that people recognize achievements." Moreover, it is configured negatively by "Important to have a good time" and "Important to understand different people." In that way, it is a component that is characterized by affective autonomy. 


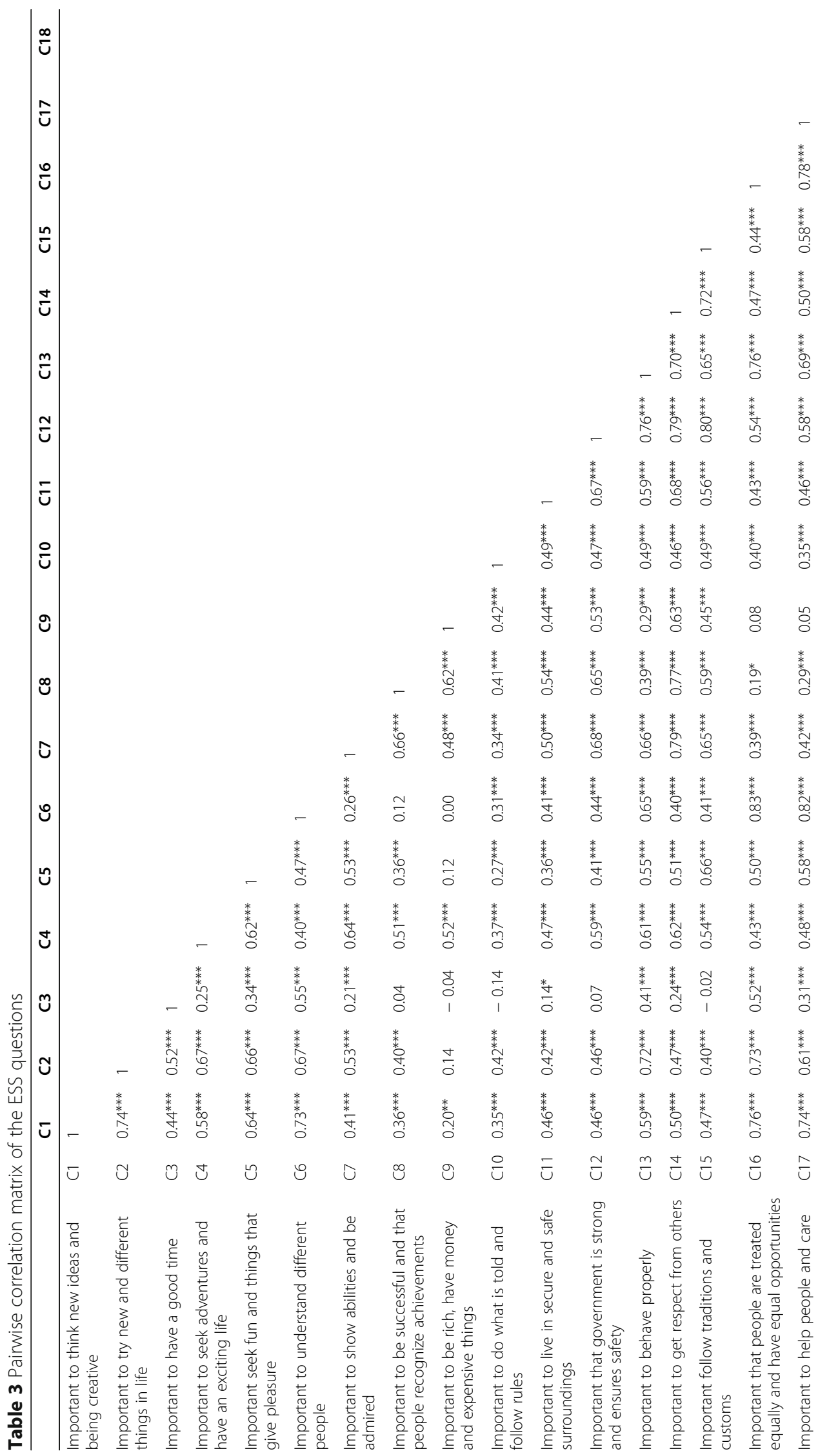




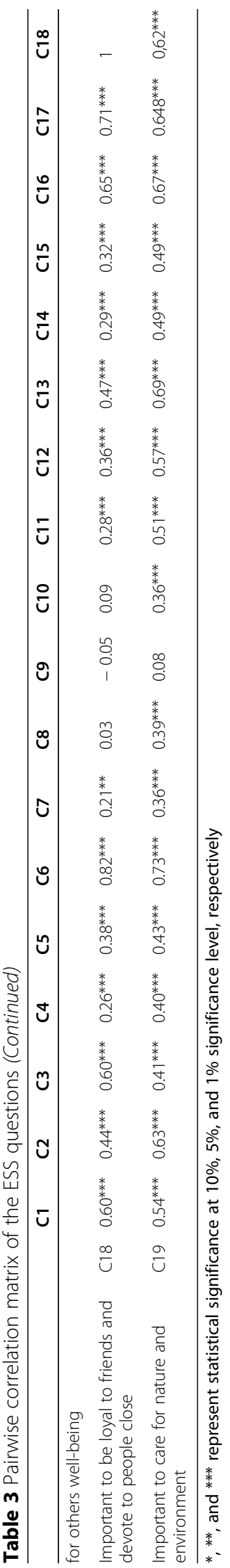


Table 4 PCA for conservatism/embeddedness vs autonomy

\begin{tabular}{lll}
\hline & PC1 & PC2 \\
\hline Important to think new ideas and being creative & $\mathbf{0 . 4 0}$ & -0.19 \\
Important to try new and different things in life & $\mathbf{0 . 4 2}$ & -0.11 \\
Important to have a good time & 0.26 & $-\mathbf{0 . 4 7}$ \\
Important to seek adventures and have an exciting life & 0.38 & 0.23 \\
Important to seek fun and things that give pleasure & 0.38 & 0.04 \\
Important to understand different people & 0.34 & $-\mathbf{0 . 4 4}$ \\
Important to show abilities and be admired & 0.34 & $\mathbf{0 . 4 3}$ \\
Important to be successful and that people recognize achievements & 0.27 & $\mathbf{0 . 5 5}$ \\
Eigenvalue & 4.42 & $\mathbf{1 . 4 3}$ \\
Var & $55.28 \%$ & $\mathbf{1 7 . 8 9 \%}$ \\
\hline In bold are presented those values above 0.4 or below -0.4 , since there are the ESS questions that more significantly \\
shape the principal components
\end{tabular}

Table 5 presents the Kaiser-Meyer-Olkin (KMO) test in order to examine the potential to use a factor analysis to the variables that express conservatism/embeddedness vs autonomy.

All values are above 0.5 indicating that the PCA is a suitable analysis for the variables used to express conservatism/embeddedness vs autonomy.

Table 6 presents the PCA for the "hierarchy vs egalitarianism" cultural value.

The first two principal components are used. The first one has an eigenvalue of 3.07 and is related to $61.43 \%$ of total variance. It is positively configured by the following questions: "Important to do what is told and follow rules," "Important to live in secure and safe surroundings," "Important that government is strong and ensures safety," and "Important to behave properly." In that way, it is a component that is characterized by power and security and thus hierarchy.

The second one has an eigenvalue of 0.76 and is related to $15.40 \%$ of total variance. It is positively configured by the question "Important to be rich, have money and expensive things" and negatively by "Important to behave properly." In that way, it is a component that is characterized by power and non-conformity and thus hierarchy as well.

Table 7 presents the KMO test in order to examine the potential to use a factor analysis to the variables that express hierarchy vs egalitarianism.

All values are above 0.5 indicating that the PCA is a suitable analysis for the variables used to express hierarchy vs egalitarianism.

Table 8 presents the PCA for the "mastery vs harmony" cultural value.

Table $5 \mathrm{KMO}$ test for conservatism/embeddedness vs autonomy

\begin{tabular}{ll}
\hline Important to think new ideas and being creative & 0.84 \\
Important to try new and different things in life & 0.89 \\
Important to have a good time & 0.85 \\
Important to seek adventures and have an exciting life & 0.89 \\
Important to seek fun and things that give pleasure & 0.91 \\
Important to understand different people & 0,80 \\
Important to show abilities and be admired & 0.80 \\
Important to be successful and that people recognize achievements & 0.75 \\
Overall & 9.85 \\
\hline
\end{tabular}


Table 6 PCA for hierarchy vs egalitarianism

\begin{tabular}{lll}
\hline & PC1 & PC2 \\
\hline Important to be rich, have money and expensive things & 0.37 & $\mathbf{0 . 8 1}$ \\
Important to do what is told and follow rules & $\mathbf{0 . 4 1}$ & 0.17 \\
Important to live in secure and safe surroundings & $\mathbf{0 . 4 8}$ & -0.09 \\
Important that government is strong and ensures safety & $\mathbf{0 . 5 1}$ & -0.15 \\
Important to behave properly & $\mathbf{0 . 4 6}$ & $-\mathbf{0 . 5 3}$ \\
Eigenvalue & 3.07 & 0.76 \\
Var & $61.43 \%$ & $15.40 \%$ \\
\hline
\end{tabular}

In bold are presented those values above 0.4 or below -0.4 , since there are the ESS questions that more significantly shape the principal components

The first two principal components are used. The first one has an eigenvalue of 4.57 and is related to $65.31 \%$ of total variance. It is positively shaped by "Important that people are treated equally and have equal opportunities," "Important to help people and care for others well-being," and "Important to understand different people." In that way, it is characterized by benevolence and thus mastery.

The second one has an eigenvalue of 1.15 and is related to $16.49 \%$ of total variance. It is positively shaped by "Important to get respect from others" and "Important to follow traditions and customs." In that way, it is characterized by tradition and thus mastery as well.

Table 9 presents the KMO test in order to examine the potential to use a factor analysis to the variables that express mastery vs harmony.

All values are above 0.5 indicating that the PCA is a suitable analysis for the variables used to express mastery vs harmony.

Table 10 presents the results after estimating Eq. (1) where the dependent variable is patent applications. Each column represents a different estimation of Eq. 1 since different independent variables are used.

Regression 4 shows that affective autonomy negatively affects patent applications. The same holds for mastery (regression 6) which negatively affect patents applications as well.

Table 11 presents the results when the gross domestic spending on R\&D is the depended variable.

Regressions 7 and 8 show a statistically significant and negative effect of hierarchy on gross domestic spending on R\&D. Moreover, regression 10 shows there is a statistically significant effect, which means that affective autonomy negatively affects gross domestic spending on R\&D. The same holds for mastery (regression 12) which negatively affect gross domestic spending on R\&D as well.

Table $7 \mathrm{KMO}$ test for hierarchy vs egalitarianism

\begin{tabular}{ll}
\hline Important to be rich, have money, and expensive things & 0.66 \\
Important to do what is told and follow rules & 0.84 \\
Important to live in secure and safe surroundings & 0.87 \\
Important that government is strong and ensures safety & 0.69 \\
Important to behave properly & 0.68 \\
Overall & 0.74
\end{tabular}


Table 8 PCA for mastery vs harmony

\begin{tabular}{lll}
\hline & PC1 & PC2 \\
\hline Important to get respect from others & 0.30 & $\mathbf{0 . 6 2}$ \\
Important to follow traditions and customs & 0.31 & $\mathbf{0 . 6 0}$ \\
Important that people are treated equally and have equal opportunities & $\mathbf{0 . 4 1}$ & -0.15 \\
Important to help people and care for others well-being & $\mathbf{0 . 4 2}$ & -0.08 \\
Important to be loyal to friends and devote to people close & 0.38 & -0.38 \\
Important to care for nature and environment & 0.39 & -0.03 \\
Eigenvalue & 4.57 & 1.15 \\
Var & $65.31 \%$ & $16.49 \%$ \\
\hline In bold are presented those values above 0.4 or below -0.4 , since there are the ESS questions that more significantly \\
shape the principal components
\end{tabular}

Table 12 presents the results when the number of researchers per 1000 people employed is the depended variable.

As in Table 8, in Table 12 regressions 13 and 14 show a statistically significant and negative effect of hierarchy on the number of researchers per 1000 people employed. Moreover, regression 16 shows there is a statistically significant effect, which means that affective autonomy negatively affects the number of researchers per 1000 people employed. The same holds for mastery (regression 18) which negatively affect the number of researchers per 1000 people employed as well.

Table 13 presents the results when the number of government researchers is used as the depended variable.

The same results hold for the case of government researchers as well. In Table 13, regression 20 shows a statistical significant and negative effect of hierarchy on the number of government researchers. Moreover, regression 22 shows there is a statistically significant effect, which means that affective autonomy negatively affects the number of government researchers. The same holds for mastery (regressions 23 and 24) which negatively affect the number of government researchers as well.

Finally, Table 14 presents the estimation of Eq. (2) where the dependent variable is economic development.

Investigating the effects of culture on economic development, in Table 14 regression 26 shows a statistically significant and negative effect of hierarchy on economic development. Moreover, regression 28 shows there is a statistically significant effect, which means that affective autonomy negatively affects economic development, while the same holds for mastery (regression 30).

Table $9 \mathrm{KMO}$ test for mastery vs harmony

\begin{tabular}{ll}
\hline Important to get respect from others & 0.75 \\
Important to follow traditions and customs & 0.72 \\
Important that people are treated equally and have equal opportunities & 0.83 \\
Important to help people and care for others well-being & 0.79 \\
Important to be loyal to friends and devote to people close & 0.83 \\
Important to care for nature and environment & 0.89 \\
Overall & 0.81
\end{tabular}


Table 10 The effect of culture on patent applications

\begin{tabular}{|c|c|c|c|c|c|c|}
\hline \multirow{2}{*}{$\begin{array}{l}\text { Dependent variable } \\
\text { Independent variables }\end{array}$} & \multicolumn{6}{|c|}{ Patent applications } \\
\hline & (1) & (2) & (3) & (4) & (5) & (6) \\
\hline Constant & $2626.1(0.27)$ & $1909.4(0.19)$ & $1666.1(0.17)$ & $\begin{array}{l}-1081.4 \\
(-0.12)\end{array}$ & $\begin{array}{l}1224.9 \\
(0.13)\end{array}$ & $\begin{array}{l}659.7 \\
(0.08)\end{array}$ \\
\hline $\begin{array}{l}\text { Hierarchy vs } \\
\text { egalitarianism-PC1 }\end{array}$ & $\begin{array}{l}-1502.3 \\
(-0.95)\end{array}$ & & & & & \\
\hline $\begin{array}{l}\text { Hierarchy vs } \\
\text { egalitarianism-PC2 }\end{array}$ & & $\begin{array}{l}-1689.2 \\
(-0.59)\end{array}$ & & & & \\
\hline $\begin{array}{l}\text { Conservatism/embeddedness } \\
\text { vs autonomy-PC1 }\end{array}$ & & & $\begin{array}{l}-392.0 \\
(-0.27)\end{array}$ & & & \\
\hline $\begin{array}{l}\text { Conservatism/embeddedness } \\
\text { vs autonomy-PC2 }\end{array}$ & & & & $\begin{array}{l}-3766.9^{*} \\
(-1.79)\end{array}$ & & \\
\hline Mastery vs harmony-PC1 & & & & & $231.1(0.15)$ & \\
\hline Mastery vs harmony-PC2 & & & & & & $\begin{array}{l}-4170.6^{*} \\
(-1.67)\end{array}$ \\
\hline$N$ & 101 & 101 & 99 & 99 & 101 & 101 \\
\hline$R^{2}$ & $6.36 \%$ & $2.92 \%$ & $1.3 \%$ & $18.25 \%$ & $1.09 \%$ & $16.42 \%$ \\
\hline$F$-stat & 0.51 & 0.23 & 0.10 & 1.67 & 0.08 & 1.47 \\
\hline
\end{tabular}

The $t$ statistics values are displayed in parentheses. *represents statistical significance at $10 \%$ significance level. Each column represents a separate regression

\section{Conclusions}

The analysis provided by the present paper concludes that there is significant effect of culture on innovation and economic development in the Eurozone countries during the period from 2002 up to 2018. In other words, the way culture has evolved during the last two decades in Eurozone, acts like a break for innovation outcomes as well as economic development.

The main cultural dimensions emerged as to hinder innovation and economic development are the prevalence of hierarchy, affective autonomy, and mastery. These results hold for all different dependent variables used in the analysis.

Table 11 The effect of culture on gross domestic spending on R\&D

\begin{tabular}{|c|c|c|c|c|c|c|}
\hline \multirow{2}{*}{$\begin{array}{l}\text { Dependent variable } \\
\text { Independent variables }\end{array}$} & \multicolumn{6}{|c|}{ Gross domestic spending on R\&D } \\
\hline & (7) & (8) & (9) & (10) & (11) & (12) \\
\hline & $2.23^{* * *}(3.35)$ & $1.94^{* *}(2.78)$ & $1.77^{* *}(2.19)$ & $1.24^{*}(2.01)$ & $1.84^{* *}(2.34)$ & $1.59 * * *(2.96)$ \\
\hline Hierarchy vs egalitarianism-PC1 & $\begin{array}{l}-0.24^{* *} \\
(-2.55)\end{array}$ & & & & & \\
\hline Hierarchy vs egalitarianism-PC2 & & $\begin{array}{l}-0.33^{*} \\
(-1.97)\end{array}$ & & & & \\
\hline $\begin{array}{l}\text { Conservatism/embeddedness vs } \\
\text { autonomy-PC1 }\end{array}$ & & & $\begin{array}{l}-0.02 \\
(-0.23)\end{array}$ & & & \\
\hline $\begin{array}{l}\text { Conservatism/embeddedness vs } \\
\text { autonomy-PC2 }\end{array}$ & & & & $\begin{array}{l}-0.37^{* * *} \\
(-3.13)\end{array}$ & & \\
\hline Mastery vs harmony-PC1 & & & & & $\begin{array}{l}-0.01 \\
(-0.12)\end{array}$ & \\
\hline Mastery vs harmony-PC2 & & & & & & $\begin{array}{l}-0.49^{* * *} \\
(-3.98)\end{array}$ \\
\hline$N$ & 107 & 107 & 105 & 105 & 107 & 107 \\
\hline$R^{2}$ & $32.09 \%$ & $22.22 \%$ & $15.89 \%$ & $41.17 \%$ & $18.92 \%$ & $53.33 \%$ \\
\hline F-stat & $3.31^{* *}$ & 2.01 & 0.03 & $4.9^{* *}$ & 0.04 & $8.00^{* * *}$ \\
\hline
\end{tabular}

The $t$ statistics values are displayed in parentheses. ${ }^{*},{ }^{*}$, and ${ }^{* * *}$ represent statistical significance at $10 \%, 5 \%$, and $1 \%$ significance level, respectively. Each column represents a separate regression 
Table 12 The effect of culture on the number of researchers per 1,000 people employed

\begin{tabular}{|c|c|c|c|c|c|c|}
\hline \multirow{2}{*}{$\begin{array}{l}\text { Dependent variable } \\
\text { Independent variables }\end{array}$} & \multicolumn{6}{|c|}{ Researchers per 1000 people employed } \\
\hline & (13) & (14) & (15) & (16) & (17) & (18) \\
\hline Constant & $\begin{array}{l}7.73^{* * *} \\
(3.09)\end{array}$ & $\begin{array}{l}6.66^{* *} \\
(2.55)\end{array}$ & $\begin{array}{l}7.02^{* *} \\
(2.48)\end{array}$ & $\begin{array}{l}4.69^{*} \\
(2.03)\end{array}$ & $\begin{array}{l}6.50^{* *} \\
(2.28)\end{array}$ & $\begin{array}{l}5.67^{* * *} \\
(2.88)\end{array}$ \\
\hline Hierarchy vs egalitarianism-PC1 & $\begin{array}{l}-0.80^{* *} \\
(-2.29)\end{array}$ & & & & & \\
\hline Hierarchy vs egalitarianism-PC2 & & $\begin{array}{l}-1.03^{*} \\
(-1.65)\end{array}$ & & & & \\
\hline $\begin{array}{l}\text { Conservatism/embeddedness vs } \\
\text { autonomy-PC1 }\end{array}$ & & & $\begin{array}{l}-0.38 \\
(-1.05)\end{array}$ & & & \\
\hline $\begin{array}{l}\text { Conservatism/embeddedness vs } \\
\text { autonomy-PC2 }\end{array}$ & & & & $\begin{array}{l}-1.26^{* * *} \\
(-2.84)\end{array}$ & & \\
\hline Mastery vs harmony-PC1 & & & & & $\begin{array}{l}-0.19 \\
(-0.46)\end{array}$ & \\
\hline Mastery vs harmony-PC2 & & & & & & $\begin{array}{l}-1.75^{* * *} \\
(-3.85)\end{array}$ \\
\hline$N$ & 106 & 106 & 104 & 104 & 106 & 106 \\
\hline$R^{2}$ & $28.02 \%$ & $52.87 \%$ & $25.04 \%$ & $60.17 \%$ & $60.26 \%$ & $52.13 \%$ \\
\hline F-stat & $2.72^{*}$ & 1.44 & 0.67 & $4.20^{* *}$ & 0.20 & $7.62^{* * *}$ \\
\hline
\end{tabular}

The $t$ statistics values are displayed in parentheses. ${ }^{*}, * *$, and ${ }^{* * *}$ represent statistical significance at $10 \%, 5 \%$, and $1 \%$ significance level, respectively. Each column represents a separate regression

This means that in societies where hierarchy prevails innovation and economic development are hindered. In hierarchical societies, there exists hierarchical organization of available resources but also individuals who act and socialize are based on the specific roles that have been assigned to them through this societal structure, acting based on self-control. Since the Schwartz's values also have an opposite pole, it seems that when

Table 13 The effect of culture on the number of government researchers

\begin{tabular}{|c|c|c|c|c|c|c|}
\hline \multirow{2}{*}{$\begin{array}{l}\text { Dependent variable } \\
\text { Independent variables }\end{array}$} & \multicolumn{6}{|c|}{ Government researchers } \\
\hline & (19) & (20) & (21) & $(22)$ & (23) & (24) \\
\hline Constant & $\begin{array}{l}12586.7^{* * *} \\
(4.71)\end{array}$ & $\begin{array}{l}12620.61^{* * *} \\
(4.97)\end{array}$ & $\begin{array}{l}12648.94^{* * *} \\
(4.24)\end{array}$ & $\begin{array}{l}12523.95^{* * *} \\
(4.35)\end{array}$ & $\begin{array}{l}12913.87^{* * *} \\
(4.47)\end{array}$ & $\begin{array}{l}12662.45^{* * *} \\
(4.54)\end{array}$ \\
\hline $\begin{array}{l}\text { Hierarchy vs } \\
\text { egalitarianism-PC1 }\end{array}$ & $\begin{array}{l}-171.4 \\
(-0.50)\end{array}$ & & & & & \\
\hline $\begin{array}{l}\text { Hierarchy vs } \\
\text { egalitarianism-PC2 }\end{array}$ & & $\begin{array}{l}-1301.2^{* *} \\
(-2.27)\end{array}$ & & & & \\
\hline $\begin{array}{l}\text { Conservatism/ } \\
\text { embeddedness vs } \\
\text { autonomy-PC1 }\end{array}$ & & & $\begin{array}{l}159.8 \\
(0.55)\end{array}$ & & & \\
\hline $\begin{array}{l}\text { Conservatism/ } \\
\text { embeddedness vs } \\
\text { autonomy-PC2 }\end{array}$ & & & & $\begin{array}{l}-1592.2^{* *} \\
(-2.13)\end{array}$ & & \\
\hline Mastery vs harmony-PC1 & & & & & $\begin{array}{l}726.5^{* *} \\
(2.34)\end{array}$ & \\
\hline Mastery vs harmony-PC2 & & & & & & $\begin{array}{l}-2009.4^{* * *} \\
(-3.04)\end{array}$ \\
\hline$N$ & 102 & 102 & 100 & 100 & 102 & 102 \\
\hline$R^{2}$ & $2.62 \%$ & $8.12 \%$ & $3.7 \%$ & $17.03 \%$ & $9.58 \%$ & $21.14 \%$ \\
\hline F-stat & 0.25 & $5.17^{* *}$ & 0.30 & $4.52^{* *}$ & $5.49^{* *}$ & $9.23^{* * *}$ \\
\hline
\end{tabular}

The $t$ statistics values are displayed in parentheses. ${ }^{* *}$ and ${ }^{* * *}$ represent statistical significance at $5 \%$ and $1 \%$ significance level, respectively. Each column represents a separate regression 
Table 14 The effect of culture on economic development

\begin{tabular}{|c|c|c|c|c|c|c|}
\hline \multirow{2}{*}{$\begin{array}{l}\text { Dependent variable } \\
\text { Independent variables }\end{array}$} & \multicolumn{6}{|c|}{ Economic development } \\
\hline & $(25)$ & (26) & (27) & (28) & (29) & (30) \\
\hline Constant & $\begin{array}{l}44.19^{* * *} \\
(3.57)\end{array}$ & $\begin{array}{l}42.56^{* * *} \\
(3.90)\end{array}$ & $\begin{array}{l}37.83^{* * *} \\
(2.96)\end{array}$ & $\begin{array}{l}34.69^{* * *} \\
(3.01)\end{array}$ & $\begin{array}{l}38.23^{* * *} \\
(3.08)\end{array}$ & $\begin{array}{l}37.61^{* * *} \\
(3.39)\end{array}$ \\
\hline Hierarchy vs egalitarianism-PC1 & $\begin{array}{l}-1.85 \\
(-1.06)\end{array}$ & & & & & \\
\hline Hierarchy Vs egalitarianism-PC2 & & $\begin{array}{l}-5.69^{* *} \\
(-2.15)\end{array}$ & & & & \\
\hline $\begin{array}{l}\text { Conservatism/embeddedness } \\
\text { vs autonomy-PC1 }\end{array}$ & & & $\begin{array}{l}1.19 \\
(0.71)\end{array}$ & & & \\
\hline $\begin{array}{l}\text { Conservatism/embeddedness } \\
\text { vs autonomy-PC2 }\end{array}$ & & & & $\begin{array}{l}-4.31^{*} \\
(-1.92)\end{array}$ & & \\
\hline Mastery vs harmony-PC1 & & & & & $\begin{array}{l}1.61 \\
(0.89)\end{array}$ & \\
\hline Mastery vs harmony-PC2 & & & & & & $\begin{array}{l}-5.26^{* *} \\
(-2.04)\end{array}$ \\
\hline$N$ & 107 & 107 & 105 & 105 & 107 & 107 \\
\hline$R^{2}$ & $13.66 \%$ & $26.03 \%$ & $4.5 \%$ & $31.68 \%$ & $26.34 \%$ & $23.80 \%$ \\
\hline F-stat & 0.69 & $2.46^{*}$ & 0.33 & 1.94 & 0.47 & 2.19 \\
\hline
\end{tabular}

The $t$ statistics values are displayed in parentheses. ${ }^{*}, * *$, and ${ }^{* * *}$ represent statistical significance at $10 \%, 5 \%$, and $1 \%$ significance level, respectively. Each column represents a separate regression

instead of hierarchy egalitarianism holds in a society, all available resources are distributed equally while at the same time individuals share the same interests and are taken into account as moral equals. Thus, egalitarianism promotes innovation and economic development.

Moreover, in societies where affective autonomy prevails, negative effects on innovation and economic development prevail since in affective autonomy individuals are independent regarding affectively positive experiences in their life. On the other side, in societies where embeddedness prevails, innovation and economic development are positively affected based on the fact that social relationships such us having shared goals, acquiring a social identity, having a shared way of living, motivate individuals, and push them on acting collectively.

Finally, when mastery prevails, there are some obstacles to the procedure of innovation and economic development, since individuals try to succeed through mastering and changing their environment as well as through directing it based on which are their interests. On the other side, harmony may promote innovation and economic development since individuals in this case accept their environment and do not try to master and change it but to preserve it.

These results may be critical for governments and policymakers that have to make decisions and provide solutions to economies and societies characterized by specific cultural values. Understanding the way a society acts, behaves, and makes decisions is critical for the choice of effective policy responses. When a society is not ready to accept a policy change, this would result in policy failures and ineffectiveness in policy responses. Policymakers should realize that ignoring cultural factors leads them to a completely wrong direction on how to choose appropriate policies. This affects innovation outcomes, economic development, and in a more general context the long run sustainability of economic system. Thus, based on the results of the analysis, 
governments should concentrate on promoting values such as egalitarianism, embeddedness, and harmony in their societies. One way to do so is through education but policymakers have to wait long to gain results, since in this way culture can change only in the long run. In the short-run, policy makers could use nudging, since nudge policies aim at designing an "architecture of choices" for individuals, to project the choice that is considered beneficial to the individual and/or society as a whole, without modifying the number or nature of the options available. But even if policymakers will not be able to successfully alter the cultural values of a society, they should be able to select the appropriate policies that fit to the society.

Abbreviations

ESS: European Social Survey; FE: Fixed effects; KMO: Kaiser-Meyer-Olkin; OECD: Organization for Economic Co-operation and Development; OLS: Ordinary least squares; PCA: Principal component analyses; PC: Principal components; R\&D: Research and development

\section{Acknowledgements}

I would like to thank Dr. Kyriaki Kafka for reading and providing feedback on the manuscript.

\section{Author's contributions}

The author(s) read and approved the final manuscript.

\section{Funding}

Not applicable.

Availability of data and materials

The data used were gathered from free available sources.

\section{Declaration}

\section{Competing interests}

The author declares no competing interests.

Received: 22 April 2021 Accepted: 3 May 2021

Published online: 09 July 2021

\section{References}

Adebayo, O. P., Worlu, R. E., Moses, C. L., \& Ogunnaike, O. O. (2020). An integrated organisational culture for sustainable environmental performance in the Nigerian Context. Sustainability, 12(20), 8323. https://doi.org/10.3390/su12208323.

Bakas, D., Kostis, P. C., \& Petrakis, P. E. (2020). Culture and labor productivity. an empirical investigation. Economic Modelling, 85, 233-243. https://doi.org/10.1016/j.econmod.2019.05.020.

Barnett, H. G. (1953). Innovation: the basis of cultural change. McGraw Hill.

Carta, M., Ronsivalle, D., \& Lino, B. (2020). Inner archipelagos in Sicily. From culture-based development to creativity-oriented evolution. Sustainability, 12(18), 7452. https://doi.org/10.3390/su12187452.

Fernandez-Jardon, C., Martinez-Cobas, X., \& Martinez-Ortiz, F. (2020). Technology and culture in subsistence small businesses. Sustainability, 12(22), 9694. https://doi.org/10.3390/su12229694.

Harrison, E. L., \& Huntington, P. S. (2000). Culture Matters: How Values Shape Human Progress. Basic Books.

Hofstede, G. (1984). Culture's consequences: international differences in work-related values. Sage.

Hofstede, G. (1980). Culture's consequences: international differences in work-related values. Sage Publications.

Jaskyte, K., \& Dressler, W. W. (2004). Studying culture as an integral aggregate variable: organizational culture and innovation in a group of nonprofit organizations. Field Methods, 16(3), 265-284. https://doi.org/10.1177/1525822X03262281.

Kafka, K. I. (2020). Economic theory and economic reality: a continuously dialectic relationship. In P. C. Kostis (Ed.), Bridging Microeconomics and Macroeconomics and the Effects on Economic Development and Growth. IGI Global, ISBN13: 9781799849339. https://doi.org/10.4018/978-1-7998-4933-9.

Kafka, K. I., Kostis, P. C., \& Petrakis, P. E. (2020). Why coevolution of culture and institutions matters for economic development and growth? In R. M. Yonk (Ed.), Economic-Financial Development and Cultural Transformation ISBN 978-1-78985-938-6.

Kostis, P. C., Kafka, K. I., \& Petrakis, P. E. (2018). Cultural change and innovation performance. Journal of Business Research, 88, 306-313. https://doi.org/10.1016/j.jbusres.2017.12.010.

Leal-Rodriguez, A. L., Ariza-Montes, J. A., Roldan, J. L., \& Leal-Millan, A. G. (2014). Absorptive capacity, innovation and cultural barriers: a conditional mediation model. Journal of Business Research, 67(5), 763-768. https://doi.org/10.1016/j.jbusres.2 013.11 .041$.

Majidi, M. (2010). Invest in diversity as a competitive advantage. In A vision on cultural diversity, (vol. 6). ADP publication.

Michna, A., \& Kmieciak, R. (2020). Open-mindedness culture, knowledge-sharing, financial performance, and industry 4.0 in SMEs. Sustainability, 12(21), 9041. https://doi.org/10.3390/su12219041.

Mohamad, A. A., Ramayah, T., \& Lo, M. C. (2020). Sustainable knowledge management and firm innovativeness: the contingent role of innovative culture. Sustainability, 12(17), 6910. https://doi.org/10.3390/su12176910.

Molina-Ramirez, E., \& Barba-Sanchez, V. (2021). Embeddedness as a differentiating element of indigenous entrepreneurship: insights from Mexico. Sustainability, 13(4), 2117. https://doi.org/10.3390/su13042117. 
North, D. (1990). Institutions, institutional change and economic performance. Cambridge University Press. https://doi.org/10.1 017/CBO9780511808678.

Ober, J. (2020). Innovation adoption: empirical analysis on the example of selected factors of organizational culture in the IT industry in Poland. Sustainability, 12(20), 8630. https://doi.org/10.3390/su12208630.

OECD (2021). Gross domestic spending on R\&D (indicator). https://doi.org/10.1787/d8b068b4-en (Accessed on 30 Jan 2021).

Park, S. O., Choi, S. U., Kim, S. T., \& Na, H. J. (2021). The relationship between corporate culture and value at different life cycle stages. Sustainability, 13(4), 2334. https://doi.org/10.3390/su13042334.

Petrakis, P. E. (2014). Culture, growth and economic policy, (p. 250). Springer, ISBN 978-3-642-41439-8.

Petrakis, P. E., \& Kostis, P. C. (2013). Economic growth and cultural change. Journal of Socio- Economics, 47(C), 147-157. https:// doi.org/10.1016/j.socec.2013.02.011.

Petrakis, P. E., Kostis, P. C., \& Kafka, I. K. (2016). Secular stagnation, faltering innovation, and high uncertainty: New-era entrepreneurship appraisal using knowledge-based thinking. Journal of Business Research, 69(5), 1909-1913. https://doi. org/10.1016/j.jbusres.2015.10.078.

Petrakis, P. E., Kostis, P. C., \& Valsamis, D. G. (2015). Innovation and competitiveness: culture as a long-term strategic instrument during the European great recession. Journal of Business Research, 68(7), 1436-1438. https://doi.org/10.1016/j. jbusres.2015.01.029.

Rothwell, R., \& Wissema, H. (1986). Technology, culture, and public policy. Technovation, 4(2), 91-115. https://doi.org/10.1016/ 0166-4972(86)90002-7

Schwartz, S. H. (1992). Universals in the content and structure of values: Theory and empirical tests in 20 countries. In M. Zanna (Ed.), Advances in experimental social psychology, (vol. 25, pp. 1-65). Academic Press. https://doi.org/10.1016/ S0065-2601(08)60281-6.

Schwartz, S. H. (2004). Mapping and interpreting cultural differences around the world. In H. Vinken, J. Soeters, \& P. Ester (Eds. ), Comparing cultures, dimensions of culture in a comparative perspective, (pp. 43-73). Brill.

Schwartz, S. H. (2006). Les valeurs de base de la personne: Théorie, mesures et applications [Basic human values: Theory, measurement, and applications]. Revue Française de Sociologie, 47, 249-288.

Schwartz, S. H. (2012). An Overview of the Schwartz Theory of Basic Values. Online Readings in Psychology and Culture, 2(1). https://doi.org/10.9707/2307-0919.1116.

Shane, S. (1993). Cultural influences on national rates of innovation. Journal of Business Venturing, 8(1), 59-73. https://doi.org/1 $0.1016 / 0883-9026(93) 90011-S$.

Shane, S. (1995). Uncertainty avoidance and the preference for innovation championing role. Journal of International Business Studies, 26(1), 47-68. https://doi.org/10.1057/palgrave.jibs.8490165.

Shapero, A., \& Sokol, L. (1982). Social dimensions of entrepreneurship. In C. A. Kent, D. L. Sexton, \& K. H. Vesper (Eds.), Encyclopaedia of entrepreneurship. Prentice Hall.

Smith, P. B., \& Schwartz, S. H. (1997). Values. In J. W. Berry, M. H. Segall, \& C. Kagitcibasi (Eds.), Handbook of cross-cultural psychology, (vol. 3, 2nd ed., pp. 77-118). Allyn \& Bacon.

Triandis, H. C. (2009). Ecological determinants of cultural variation. In R. S. Wyer, C. Chiu, \& Y. Hong (Eds.), Understanding culture: theory, research and application, (pp. 189-210). Psychology Press.

Ulijn, J., \& Weggeman, M. (2001). Towards an innovation culture: what are its national, corporate, marketing and engineering aspects. Some experimental evidence. In C. L. Cooper, S. Cartwright, \& C. P. Early (Eds.), The international handbook of organiza- tional culture and climate, (pp. 487-517). Wiley.

Westwood, R., \& Low, D. R. (2003). The multicultural muse. Culture, creativity and in- novation. International Journal of Cross Cultural Management, 3(2), 235-259.

Yun, J. J., Zhao, X., Jung, K., \& Yigitcanlar, T. (2020). The culture for open innovation dynamics. Sustainability, 12(12), 5076. https://doi.org/10.3390/su12125076

Zhen, Z., Yousaf, Z., Radulescu, M., \& Yasir, M. (2021). Nexus of digital organizational culture, capabilities, organizational readiness, and innovation: investigation of SMEs operating in the digital economy. Sustainability, 13(2), 720. https://doi. org/10.3390/su13020720

\section{Publisher's Note}

Springer Nature remains neutral with regard to jurisdictional claims in published maps and institutional affiliations.

\section{Submit your manuscript to a SpringerOpen ${ }^{\circ}$ journal and benefit from:}

- Convenient online submission

- Rigorous peer review

- Open access: articles freely available online

- High visibility within the field

- Retaining the copyright to your article

Submit your next manuscript at $>$ springeropen.com 